УДК 378.016:51

DOI:

Вячеслав Мельник, старший викладач кафедри фундаментальних дисциплін Національної академії Національної гвардії Украӥни Людмила Алфімова, кандидат хімічних наук, доиент, завідувач кафедри фундаментальних дисциилін Національної академії Національної гвардії України

\title{
ПРОФЕСІЙНО ОРІЄНТОВАНЕ НАВЧАННЯ ВИЩОЇ МАТЕМАТИКИ ПРИ ПІДГОТОВЦІ МАЙБУТНІХ ОФІЦЕРІВ НАЦІОНАЛЬНОЇ АКАДЕМІЇ НАЦІОНАЛЬНОЇ ГВАРДІЇ УКРАЇНИ
}

Визначено необхідним впроваджувати нові методичні підходи до реалізачії професійно орієнтованого навчання математики у виші на основі поєднання фундаментальності й професійної спрямованості. Проведено аналіз стану математичної підготовки майбутніх офічерів і виявлені недоліки існуючої практики викладання, вивчена і проаналізована концепція професійно орієнтованого навчання математики у військовому виші, обтрунтовано необхідність пошуку нових методичних підходів до викладу змісту професійно орієнтованих математичних курсів з метою вдосконалення математичної освіти у військовому виті.

Проаналізовано, які елементи наукового математичного знання є професійно важливі для майбутніх офіцерів, але раніше не входили до навчальних програм, та можливість їх введення до курсу математики у військовому виші. На основі иъього аналізу розроблені рекомендації для внесення змін до навчальних програм і тематичних планів.

Ключові слова: професійно-орієнтоване навчання; майбутній офіцер; вища математика; компетентність; методичні підходи; міжпредметні зв'язки; здобувачі вищої освіти.

Jim. 8.

Vyacheslav Melnyk, Senior Lecturer of the Fundamental Disciplines Department National Academy of the National Guard of Ukraine Lyudmyla Alfimova, Ph.D.(Chemical Studies), Associate Professor, Head of the Fundamental Disciplines Department National Academy of the National Guard of Ukraine

\section{PROFESSIONALLY ORIENTED HIGHER MATHEMATICS TRAINING IN PREPARING FUTURE OFFICERS OF THE NATIONAL GUARD OF UKRAINE}

It was determined that it is necessary to introduce new methodical approaches to the implementation of professionally oriented mathematics training in higher education on the basis of a combination of fundamentalism and professional orientation.

The analysis of the state of mathematical preparation of future officers and the shortcomings of the existing practice of teaching was made; the concept of professionally oriented mathematics training in the military higher education was studied and analyzed; the necessity of finding new methodical approaches to the presentation of the content of professionally oriented mathematical courses was grounded in order to improve mathematical education in military higher education.

It was analyzed which elements of scientific mathematical knowledge are professionally important for future officers but were not previously included in the curriculum, and the possibility of their introduction into the course of mathematics in military higher education. Based on this analysis, recommendations for making changes to curricula and thematic plans were developed.

Methods of establishing inter-subject mathematical relations with general-professional and special disciplines have been developed. The main ways of implementation are considered professionally-oriented tasks, the solution of which allows modelling the main activities of the future officer.

The methodical approaches to the implementation of professionally oriented mathematics training on the basis of a combination of fundamentalism and professional orientation of the National Guard of Ukraine future officers were revealed.

The methodical system of studying higher mathematics in military higher education on the basis of a combination of fundamentalism and professional orientation of training will awaken interest to the mathematics study, increase the creative activity of higher education graduates and will improve the quality of mathematical knowledge of higher education applicants; increase the readiness of higher education graduates to study general and special disciplines, as well as to future professional activities. 


\section{ПРОФЕСІЙНООРІЄНТОВАНЕ НАВЧАННЯ ВИЩОӤ МАТЕМАТИКИПРИПДГОТОВЦІМАЙБУТНІХ ОФІЦЕРВВ НАЦІОНАЛЬНӦ̈ АКАДЕМІЇ НАЦІОНАЛЬНОЇГВАРДІЇ УКРАЇНИ}

It was determined that updating of the teaching methodology positively influenced on the motivational sphere of higher education graduates.

Keywords: professionally-oriented education; a future officer; higher mathematics; competence; methodological approaches; interpersonal relations; higher education graduates.

$\Pi$ остановка проблеми в загальному вигляді. У сучасних освітніх умовах усебічного вдосконалення стан системи військової освіти потребує пошуку нових підходів до організації освітнього процесу у військовому виші, здатних створити умови для підготовки кваліфікованих офіцерських кадрів. Випускник сучасного військового вишу повинен на високому рівні володіти професійними знаннями, причому вдосконалення підготовки фахівців неможливе без удосконалення їхньої математичної підготовки. Якщо цього не зробити, то говорити про якісну фундаментальну підготовку майбутніх офіцерів навряд чи буде доречно. Для сучасної математичної освіти у військовому виші характерний ряд негативних тенденцій. Скорочення кількості годин, що відводиться на вивчення дисциплін курсу математично-природничих дисциплін, суперечить зростаючим високим вимогам до якості фундаментальної підготовки майбутнього офіцера. Низький початковий рівень математичної підготовки створює пізнавальний бар'єр, який важко подолати і знижує мотивацію до вивчення вищої математики та інших фундаментальних дисциплін.

Тому потрібно впроваджувати нові методичні підходи до реалізації професійно орієнтованого навчання математики у виші на основі поєднання фундаментальності й професійної спрямованості.

Аналіз останніх досліджень і публікацій. Різні питання викладання математики у закладах вищої освіти, у тому числі й проблему професійно спрямованого навчання математики, розглядали в своїх працях В.В. Афанасьєв, Ю.В. Жучок, В.С. Герасимчук, Л.Е. Гризун, В.А. Садовничий, О.В. Семеніхіна, М.В Працьовитий, В.Г. Моторіна та інші.

Проблема професійної спрямованості навчання досліджувалася багатьма психологами й педагогами (С.I. Архангельський, Ю.К. Бабанський, В.С. Безрукова, В.П. Беспалько, А.А. Вербицький, М.Н. Скаткін, Н.Ф. Тализіна, В. Д. Шадриков та ін.).

Питання формування фахової компетентності у процесі навчання розглядали В.А. Петрук, О.В. Семеніхіна та ін.

Виділення невирішених раніше частин загальної проблеми, яким присвячується дана стаття. Основними проблемами, характерними для сучасного стану математичної підготовки у закладі освіти, $є$ :

- зменшення престижу математичних дисциплін та інтересу до них і, як наслідок, низька мотивація до їх вивчення;

- зменшення кількості навчального часу, відведеного на вивчення математичних дисциплін;

- застосування традиційних методів навчання і недостатній рівень застосування інноваційних технологій;

Один із напрямків вирішення цих проблем це посилення фундаментальності й професійної орієнтованості навчання вищої математики майбутніх офіцерів.

Якщо методичну систему навчання вищої математики у військовому виші розробляти на основі поєднання фундаментальності й професійної спрямованості навчання, то це дозволить:

- підвищити якість математичних знань здобувачів вищої освіти;

- підвищити готовність здобувачів вищої освіти до вивчення загальних і спеціальних дисциплін, а також до майбутньої професійної діяльності;

- пробудити інтерес до вивчення математики;

- підвищити творчу активність здобувачів вищої освіти.

Формування цілей математичної підготовки повинно здійснюватись 3 урахуванням методологічних положень компетентнісного підходу, який покликаний виявити і сформувати в освітньому процесі найбільш універсальні якості й здібності особистості. При формулюванні цілей математичної підготовки майбутніх офіцерів потрібно враховувати цілі професійної освіти, які повинні забезпечити фундаментальну, професійну і практичну підготовку, формування у здобувачів вищої освіти якостей компетентного професіонала, що здатний успішно функціонувати в умовах інформаційного суспільства $[6,7]$.

Мета та завдання статті полягають у розкритті теоретичних основ і методики реалізації професійно орієнтованого навчання математики у військовому виші на основі поєднання фундаментальності і професіоналізації.

Виклад основного матеріалу дослідження. Перспективи оновлення освіти роблять нагальним завданням підготовку професіонала, здатного до проектування власної діяльності в різних соціокультурних ситуаціях, готового знаходити шляхи розв'язання актуальних проблем незалежно від окремих обставин, виробляти особливу стратегію професійного мислення, поведінки й діяльності [4]. 


\section{ПРОФЕСІЙНООРІЄНТОВАНЕ НАВЧАННЯ ВИЩОӤ МАТЕМАТИКИПРИПІДОТОВЦІМАЙБУТНІХ ОФІЦЕРІВ НАЦІОНАЛЬНОЇ АКАДЕМІЇ НАЦІОНАЛЬНОЇ ГВАРДІЇ УКРАЇНИ}

Першочерговим завданням модернізації освіти $\epsilon$ формування фахівця високої якості й компетентності, здатного до системного узагальнення досвіду минулого та інноваційного пошуку шляхів самореалізації в умовах неперервних кардинальних змін інформаційного суспільства. [8]

Таким чином, комплексний підхід: фундаментальність і професійна спрямованість навчання розглядається як орієнтація освітнього процесу на формування мотивів, інтересів, схильностей до вивчення математичних дисциплін і як відображення у всіх компонентах методичної системи навчання математики у військових вишах специфічних особливостей, які враховують спеціалізацію майбутніх офіцерів [3].

Професійна орієнтованість навчання вищої математики у військовому виші трактується як створення засобами математики умов для цілеспрямованого й безперервного формування готовності здобувачів вищої освіти використовувати активні й глибокі математичні знання при вивченні загальних і спеціальних дисциплін, пробудження їх інтересу до вивчення математики і засвоєння професійно значущих видів діяльності. Професійна спрямованість навчання виступає як одна 3 основних вимог до процесу підготовки фахівця.

Цілі вивчення математики у військовому виші в найбільш загальному вигляді представлені як три складові: цілі навчання, цілі виховання й цілі розвитку, при цьому провідна ідея професійно орієнтованого навчання полягає в тому, що математична підготовка здобувачів вищої освіти повинна мати виражену професійну спрямованість і органічно вписуватися в підготовку випускника військового вишу як у цілісну педагогічну систему. При організації освітнього процесу здійснюється конкретизація цілей навчання на рівні навчального предмета 3 урахуванням вимог професійної підготовки.

Основними компонентами професійно орієнтованого навчання вищої математики 3 метою підвищення якості математичної освіти $є$ :

Розробка теоретичних основ професійно орієнтованого навчання у військовому виші включає:

- виділення комплексу методичних засад реалізації фундаментальності і професійної орієнтованості навчання математики у військових вишах, ієрархічно підпорядкованого системі дидактичних принципів;

- виділення з комплексу методичних принципів базових: актуалізації внутрішньопредметних зв'язків; актуалізації та синхронізації міжпредметних зв'язків; оптимізації навчального процесу;
Аналіз і коригування змісту навчальних програм з урахуванням вимог професійно орієнтованого навчання.

Процес відбору змісту професійно орієнтованого курсу математики в військовому виші з урахуванням комплексу методичних принципів і критеріїв передбачає:

- аналіз навчальних планів і програм;

- виявлення і дослідження міжпредметних зв'язків математики, загальних і спеціальних дисциплін;

- розробка банку професійно орієнтованих задач для різних форм навчання (лекційних, практичних занять, для самостійної роботи);

- поєднання традиційних методів та методів проблемного навчання;

- оновлення засобів навчання, найважливішим із яких є навчальна література.

На практиці це було реалізовано шляхом проектування професійно орієнтованого навчального математичного курсу за спеціальністю “Озброєння та військова техніка, а саме: проаналізовано рівень початкової математичної підготовки здобувачів вищої освіти. Для цього проводили бесіду та анкетування. Дані анкетування слухачів молодших курсів дозволяють зробити висновки, що багато хто з них не знає про перспективи застосування математичного апарату в спеціальних дисциплінах, рівень їх мотивації до вивчення математики можна оцінити як низький. На питання про труднощі, що виникають при вивченні вищої математики, найбільш часто зустрічалися такі відповіді: великий обсяг досліджуваного матеріалу, слабка шкільна підготовка, труднощі в опрацюванні теоретичного матеріалу підручників з математики та лекційного матеріалу через відсутність навичок в оперуванні математичної символікою, відсутність часу на самопідготовку, швидкий темп читання лекцій.

Для них проведено в межах консультативних занять спеціальний курс, розрахований на подолання розриву між шкільною й академічною програмами з математики.

Включено до розділів вищої математики відомостей професійного характеру, що мають значимість при підготовці фахівців за певною спеціальністю.

Виявлено ті теми курсу вищої математики, для яких цілком чітко простежується потреба коригування змісту, й на цій основі організовано роботу по створенню таких найважливіших засобів навчання як підручники, навчальні посібники, методичні розробки.

Проаналізовано, які елементи наукового математичного знання $є$ професійно важливі для 


\section{ПРОФЕСІЙНООРІЄНТОВАНЕ НАВЧАННЯ ВИЩОӤ МАТЕМАТИКИПРИПДГОТОВЦ МАЙБУТНІХ ОФІЦЕРІВ НАЦІОНАЛЬНОЇ АКАДЕМІЇ НАЦІОНАЛЬНОЇ ГВАРДІЇ УКРАЇНИ}

майбутніх офіцерів, але раніше не входили до навчальних програм, та можливість їх введення до курсу математики у військовому виші. На основі цього аналізу розроблені рекомендації для внесення змін до навчальних програм і тематичних планів.

Розроблено методичні прийоми встановлення міжпредметних зв'язків математики із загальнопрофесійними та спеціальними дисциплінами. В якості основного засобу реалізації розглядаються професійно орієнтовані завдання, вирішення яких дозволяє моделювати основні види діяльності майбутнього офіцера.

Необхідно використовувати будь-які можливості для ілюстрації зв'язку освітнього процесу з майбутньою професійною діяльністю, наприклад, шляхом включення в базові дисципліни конкретних прикладів, зрозумілих і цікавих курсантам, оскільки вони пов'язані з їх майбутньюю професійною діяльністю [1]. У системі навчання майбутнього офіцера велике значення має розбір повчальних прикладів і задач практичного змісту.

Завдання практичного змісту поєднують навчальну діяльність і науковий пошук, виробляють математичну та професійну інтуїцію (відшукання оптимального методу розв'язання, використовуючи відомі алгоритми рішення, принцип аналогії або інші евристичні методи), винахідливість, формують логічне мислення [2].

Також актуальним $є$ впровадження інформаційно-комунікативних технологій, що сприяє професійній спрямованості навчання, впливає на мотиваційну сферу, зумовлює формування і переведення в ранг домінуючих професійних і навчально-пізнавальних мотивів вивчення математики, які забезпечать успішність оволодіння професійними знаннями і вміннями [5].

Слід зазначити, що існують особливості у підборі завдань, пов'язаних із тимчасовими рамками вивчення дисциплін у військовому виші: базові математичні дисципліни вивчаються на першому курсі, а загально-професійні і спеціальні, як правило, пізніше. 3 цієї причини виникають труднощі у виборі тієї інформації зі спеціальних дисциплін, яка була б доступна засвоєнню здобувачами вищої освіти молодших курсів, а також може бути застосована для складання математичної задачі, що має певну інформативну цінність при вивченні математики.

3 іншого боку, з багатьма поняттями, які використовуються в навчальних дисциплінах на старших курсах, здобувачі вищої освіти вже зустрічалися в курсах фізики, теоретичної механіки, в курсі “Опір матеріалів” та деяких інших дисциплінах, тому є можливості для встановлення зв'язків супровідного характеру.

Такий підхід значно впливає на формування культури математичного мислення майбутніх офіцерів. Також сприяє розвитку інтелектуальної витривалості, тобто здатності офіцера тривалий час утримувати в свідомості складну проблему 3 метою знаходження шляхів її вирішення. Оволодіння математичними методами вирішення прикладних завдань для офіцера означає оволодіння одним 3 елементів професійної культури.

Висновки 3 даного дослідження i перспективи подальших розвідок у даному напрямку. Проведено аналіз стану математичної підготовки майбутніх офіцерів і виявлені недоліки існуючої практики викладання; вивчена i проаналізована концепція професійно орієнтованого навчання математики у військовому виші; обгрунтовано необхідність пошуку нових методичних підходів до викладу змісту професійно орієнтованих математичних курсів 3 метою вдосконалення математичної освіти у військовому виші.

Після опанування професійно орієнтованого математичного курсу здобувачам вищої освіти було запропоновано відповісти на питання: “Як Ви вважаєте, чи важливі знання з математичних дисциплін у Вашій майбутній професійній діяльності?” Результати опитування свідчать про те, що інтерес до вивчення математики від початку навчання до старших курсів змінився. Нова методика навчання позитивно вплинула на мотиваційну сферу здобувачів вищої освіти.

\section{ЛІТЕРАТУРА}

1. Вергасов В. М. Активизация познавательной деятельности студентов в высшей школе. 2-е изд., перераб. и доп. Киев, 1989. 215 с.

2. Герасимчук В. С. Професійно спрямоване викладання математики та методи його реалізації / матеріали четвертої науково-методичної конференції “Навчання математики в технічному університеті” Донецьк, 09.06.2011.

3. Гризун Л. Е. Дидактичні основи проектування модульної структури навчальної дисципліни : монографія. Харк. нац. пед. ун-т ім. Г. С. Сковороди. Харків, 2008. 302 с.

4. Моторіна В. Г. Технології навчання математики в сучасній школі: монографія. Харків, 2001. 262 с

5. Петрук В. А. Модель формування фахової компетентності в майбутніх випускників технічних ВНЗ у процесі двоступеневого навчання. е-журнал "Педагогічна наука: історія, теорія, практика, тенденції розвитку”. Архів номерів. Випуск №3. 2009. 
6. Семеніхіна О. В. До проблем організації навчального процесу у вищих навчальних закладах. Педагогічні науки: теорія, історія, інноваційні технології: наук. журнал. голов. ред. А. А. Сбруєва. Суми, 2010. № 2 (4). С. 247-252.

7. Семеніхіна О. В., Чкана Я. О. Моделювання процесу формування предметної компетентності вчителя математики на засадах компетентнісного підходу. Гуманізація навчально-виховного проиесу : збірник наукових праџь. Харків, 2017. № 4 (84). C. 112-125.

8. Семеніхіна О. В. Про реформування вищої педагогічної освіти в галузі математики. Педагогічні науки: теорія, історія, інноваційні технологї: наук. журнал / голов. ред. А. А. Сбруєва. Суми, 2014. № 5 (39). С. 347-353.

\section{REFERENCES}

1. Vergasov, V. M. (1989). Aktivizatsiya poznavatelnoy deyatelnosti studentov $v$ vysshey shkole [Activization of students' cognitive activity in higher school]. Vol. 2, Kyiv, 215 p. [in Russian].

2. Herasymchuk, V. S (2011). Profesiino spriamovane vykladannia matematyky ta metody yoho realizatsii [Professionally directed teaching of mathematics and methods of its realization]. Proceedings of the fourth scientific-methodical conference "Teaching mathematics at a technical university”. Donetsk National Technical University, Donetsk. [in Ukrainian].

3. Hryzun, L. E. (2008). Dydaktychni osnovy proektuvannia modulnoi struktury navchalnoi dystsypliny : monohrafiia [Didactic Fundamentals of Designing a Modular Structure of a Educational Discipline: Monograph]. H.S. Skovoroda Kharkiv National Pedagogical University. Kharkiv, 302 p. [in Ukrainian].
4. Motorina, V. H. (2001). Tekhnolohii navchannia matematyky $v$ suchasnii shkoli: monohrafiia [Technologies of teaching mathematics in modern school]. Kharkiv, 262 p. [in Ukrainian].

5. Petruk, V. A. (2009). Model formuvannia fakhovoi kompetentnosti v maibutnikh vypusknykiv tekhnichnykh VNZ u protsesi dvostupenevoho navchannia [The model of formation of professional competence in future graduates of technical universities in the process of two-level training]. Ejournal "Pedagogical science: history, theory, practice, trends of development”, vol. 3. 2009. [in Ukrainian].

6. Semenikhina, O. V. (2010). Do problem orhanizatsii navchalnoho protsesu u vyshchykh navchalnykh zakladakh [About problems of organization of educational process in higher educational establishments.]. Scientific journal. Pedagogical sciences: theory, history, innovative technologies. SumDPU named after A. S. Makarenko Publ. Sumy. Vol. 2 (4), pp. 247-252. [in Ukrainian].

7. Semenikhina, O. V. (2017). Modeliuvannia protsesu formuvannia predmetnoi kompetentnosti vchytelia matematyky na zasadakh kompetentnisnoho pidkhodu [Modeling the process of forming the subject competence of a mathematics teacher on the basis of a competent approach]. Humanization of the educational process: a collection of scientific works. Kharkiv, pp. 112-125. [in Ukrainian].

8. Semenikhina, O. V. (2014). Pro reformuvannia vyshchoi pedahohichnoi osvity v haluzi matematyky [About the reforming of higher pedagogical education in the field of mathematics]. Scientific journal. Pedagogical sciences: theory, history, innovative technologies. Sumy. Vol. 5 (39), pp. 347-353. [in Ukrainian].

Стаття надійшла до редакції 22.07.2019

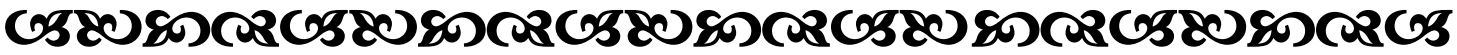

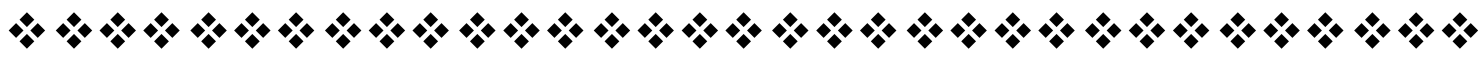 \\ “Все приходить до того, хто пращює і вміє чеқати”.}

$$
\begin{array}{r}
\text { TТомас Едісон } \\
\text { всесвітнъо відомий американський винахідник }
\end{array}
$$

"Я Бачу дуже важливе виховне завдання в тому, щоб повсякиас підтримувати, поглиблювати бажання учня бути відқривачем, реалізувати ие бажання спеціальними методами роботи".

Василь Сухомлинський украӥнсъкий педагог, публіиист

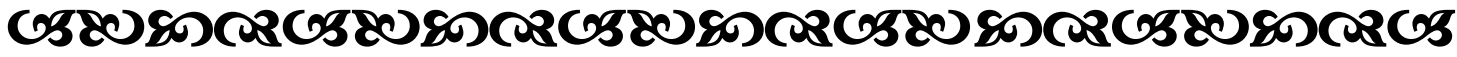

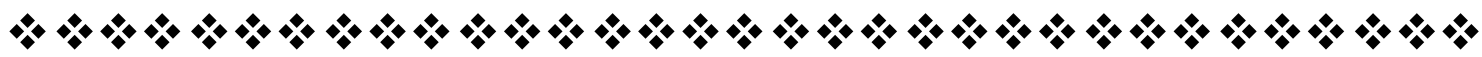

